\title{
Upgrading Biogas Using Eburru Zeolitic Rocks and Other Adsorbent Materials to Remove Carbon Dioxide and Hydrogen Sulphide
}

\author{
James K. Mbugua ${ }^{*}$, Joseph M. Mwaniki ${ }^{2}$, Damaris M. Nduta ${ }^{2}$ and Francis B. Mwaura ${ }^{2}$ \\ ${ }^{1}$ Department of Chemistry, University of Nairobi, P. O. Box 30197-00100, Nairobi, Kenya \\ ${ }^{2}$ School of Biological Sciences, University of Nairobi, P. O. Box 30197-00100, Nairobi, Kenya \\ *Corresponding author, e-mail address: djames085@gmail.com \\ Co-authors'e-mails:jmwaninki@uonbi.ac.ke,dmbui@uonbi.ac.ke; fmwaura@uonbi.ac.ke \\ Received 21 Jan 2021, Revised 11 Mar 2021, Accepted 21 Apr 2021, Published May 2021 \\ DOI: https://dx.doi.org/10.4314/tjs.v47i2.2
}

\begin{abstract}
The trace amounts of carbon dioxide and hydrogen sulfide in raw biogas lower its calorific value, cause corrosion and make it hard to compress biogas into the cylinder. Raw biogas was obtained from anaerobic digestion of cow dung and market wastes. The gas was stored in tubes or urine bag before upgrading. Natural zeolite rocks, maize cobs, steel wire, desulphurizer, and worn-out tyres were used as the upgrade materials. The composition of biogas was recorded before and after upgrading using a GP180 portable biogas analyzer from Henan, China. The measured level of raw biogas was $0.0227 \% \mathrm{H}_{2} \mathrm{~S},>20 \% \mathrm{CO}_{2}$ and $52-56 \% \mathrm{CH}_{4}$. The most efficient upgrade materials were zeolite rocks with upgrade levels of $89-93 \%$ methane. The total removal using zeolite was observed to be $75 \% \mathrm{CO}_{2}$ and $95.34 \% \mathrm{H}_{2} \mathrm{~S}$. The morphological structures of zeolitic rocks account for its higher upgrading properties compared to other materials. In addition, the porosity in these rocks mean that $\mathrm{CO}_{2}$ and $\mathrm{H}_{2} \mathrm{~S}$ were adsorbed resulting in high $\mathrm{CH}_{4}$ levels in the upgraded biogas. Other adsorbents showed upgrading properties with removal rates above $70 \%$ for both $\mathrm{H}_{2} \mathrm{~S}$ and $\mathrm{CO}_{2}$.
\end{abstract}

Keywords: Biogas, Upgrading, Natural zeolite, Bio-methane.

\section{Introduction}

For biogas to be employed in motor engines or injection into the gas network, it has to be upgraded to meet certain qualities. Globally, there are no set standards as to the specific quality for biogas yet, and therefore, reference is made to the Swedish specification for natural gas (Persson et al. 2006). In 1999, Sweden proposed a national protocol for the usage of biogas as an automobile fuel (Table 1).

Table 1: Swedish standard for bio-methane (Persson et al. 2006)

\begin{tabular}{|l|l|l|l|}
\hline Parameter & Requirement & Parameter & Requirement \\
\hline Lower Wobbe Index & $\begin{array}{l}43.9-47.3 \\
\mathrm{MJ} / \mathrm{Nm}^{3}\end{array}$ & Water dew point & $\begin{array}{l}\text { t-5, where } \mathrm{t}=\text { ambient } \\
\text { temperature }\end{array}$ \\
\hline Methane concentration & $97 \pm 2 \%$ by volume & $\mathrm{CO}_{2}+\mathrm{O}_{2}+\mathrm{N}_{2}$ & $<5 \%$ by volume \\
\hline Motor Octane Number & $>130$ & $\mathrm{O}_{2}$ & $<1 \%$ by volume \\
\hline Total sulphur & $<23 \mathrm{mg} / \mathrm{Nm}^{3}$ & $\mathrm{NH}_{3}$ & $<20 \mathrm{mg} / \mathrm{Nm}^{3}$ \\
\hline
\end{tabular}

This protocol (Table 1) is comparable to the natural gas grid. To employ biogas as a that utilized when injecting bio-methane into motor fuel or inject into gas network, 421 
upgrading is vital. Although bio-methane has a high calorific value and provides longer driving distances, the set quality standards must be met to avoid corrosion of the engines and improve burning efficiency in the engines (Persson et al. 2006)

The moisture level in raw biogas must be reduced to zero to avoid reaction with the remaining $\mathrm{SO}_{2}$ resulting in corrosion. On the other hand, the remaining $\mathrm{CO}_{2}$ interact with water vapour in biogas forming carbonic acid thereby corroding metal surfaces (Shah et al. 2016, Peterson 2009). Amirfakhri et al. (2006) reported that for biogas to be pumped through the gas system, $\mathrm{H}_{2} \mathrm{~S}$ must be reduced to levels below $0.006 \mathrm{gm} / \mathrm{m}^{3}$.

According to Pike Research (2012), the capacity of global power generation from commercial biogas facilities will increase to 29.5 gigawatts in 2022, which is more than double in 2012 (14.5 gigawatts). Biogas is a sustainable energy generated from degradation of wastes and is playing significant roles in the current energy needs. $\mathrm{CH}_{4}$ and $\mathrm{CO}_{2}$ are the major components of untreated biogas. The biogas production and contents are affected by the types of substrates. The presence of $\mathrm{CO}_{2}$ and minor gases have impacts upon biogas usability (Ryckebosch et al. 2011). The range of hydrogen sulphide in biogas is between 50 and 10,000 ppm, based on the feedstock (Chambers and Potter 2002). This gas burns in air to form $\mathrm{SO}_{2}$ and water which results in corrosion. Therefore, removal of $\mathrm{H}_{2} \mathrm{~S}$ is vital as described by Limmeechokchai and Chawan (2007), Al Mamun and Torii (2015), and $\mathrm{Cu}$ et al. (2015). Therefore, many technologies for biogas upgrading have been proposed. Among the most common removal technologies for $\mathrm{H}_{2} \mathrm{~S}$ removal from biogas are; absorption in water or acidic solution, adsorption and biological conversion to sulphur (Li et al. 2007, Yan et al. 2010). Additions of air (2-6\%) to the digester headspace result in $\mathrm{H}_{2} \mathrm{~S}$ oxidation to sulphur. In this method, $\mathrm{H}_{2} \mathrm{~S}$ is partially removed, however, overdosing of the air, may result in explosion (Wellinger and Linberg 2000). Another technique employed in biogas treatment is adsorption by microporous material.

Zeolites are crystalline, nanoporous aluminosilicates composed of $\left(\mathrm{TO}_{4}\right)$ and tetrahedral $(\mathrm{T}=\mathrm{Si}, \mathrm{Al})(\mathrm{Na}$ and Somorjai 2015). The zeolite rock sizes range from $3 \AA$ to $12 \AA$ which provides good selectivity for molecular transport into the zeolite crystals. Furthermore, the existence of active metalphase and Brønsted acid sites in zeolite micro structures determine the activity of zeolite. The composition of $\mathrm{Si} / \mathrm{Al}$ ratio also determines the acidity level and adsorption process (Cozmuta 2012, Na and Somorjai 2015). In a study by Tira et al. (2018) to purify raw biogas using zeolite rocks, they observed that activating zeolite increased the upgrading properties of the rocks.

In the current study, biogas produced from market wastes was upgraded using zeolite rocks, steel wire, tyres, desulphurizer and maize cob cartridges.

\section{Methodology}

The experiments were performed using raw biogas from cow dung feedstock and market wastes. The raw biogas used in this study was generated from cow dung mixed with water in the ratio of 1:1 as recommended by Tira et al. (2015). The substrates (cow dung from dairy cows and water was loaded into a 0.5-1.5 liters' digesters and biogas generated at psychrophilic conditions for a 10 days' retention time as described by Kamau et al. (2020). The produced biogas was then stored in urine bags or tubes before being directed to biogas scrubbing unit (Figure 1 (a)) as described by Kamau et al. (2020). Direct scrubbing from the digester was also investigated (Figure 1 (b)). Pilot scale biogas produced was also cleansed via a commercial desulphurizer, zeolite rocks and combined upgrade material cartridges. 

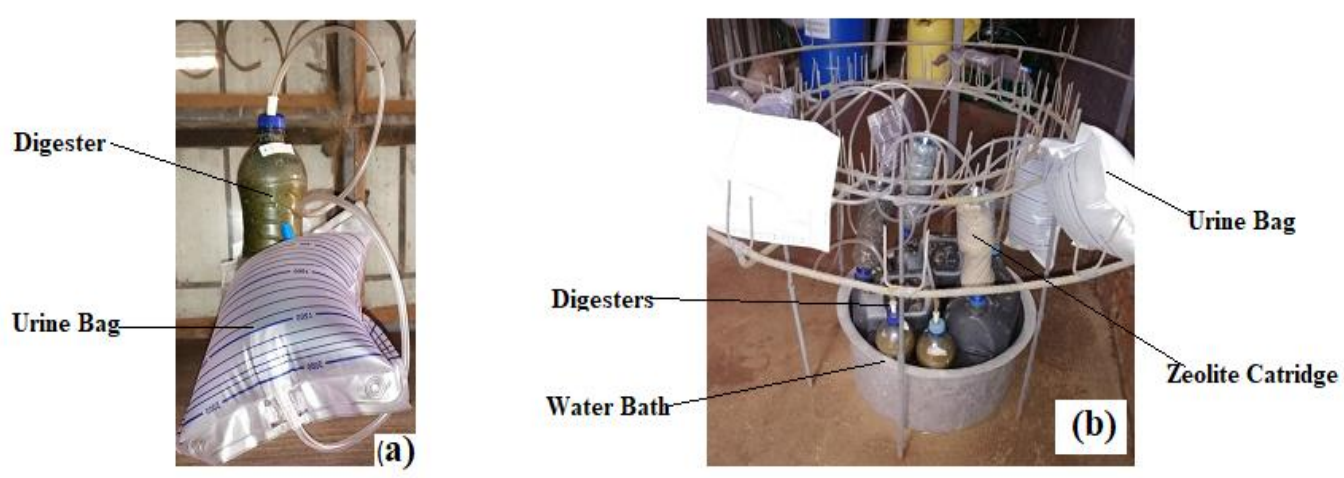

Figure 1: Photographs of (a) Biogas production and storage set-up (b) Composition measurement.

The scrubbing cartridges used in the lab scale and the pilot scale studies are shown in

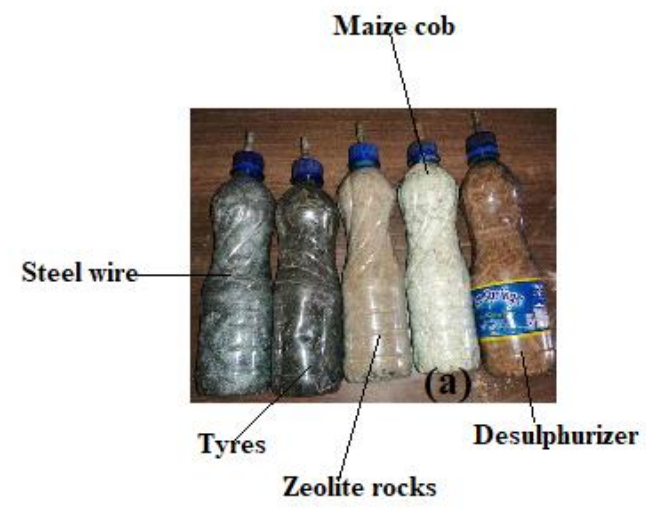

Figure 2: (a) A lab scale upgrading cartridges (b) material.

The upgrade experiments were done using zeolite rocks from Eburru, with pore size about $3 \AA$ and whose morphology was scanned using a scanning electronic microscope. The zeolite rocks preparations involved mechanical grinding and sieving using $0.85 \mathrm{~mm}$ sieve to obtain very fine homogeneous particle sizes powder. The powdered samples were then calcined at $550{ }^{\circ} \mathrm{C}$ for 2 hours to remove some of the organic and amorphous components (Waswa et al. 2020). The elemental analysis of the natural zeolitic rocks from Eburru, Nakuru County, was carried out as described by Mbugua et al. (2014). The Scanning Electron
Figures 2 a-c. The cartridges composed of well grinded particles.
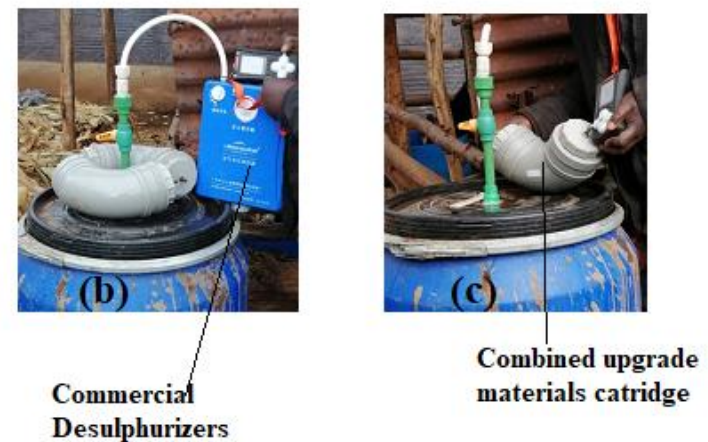

(b) Commercial desulphurizer (c) combined upgrade

Microscopy (SEM) on the zeolitic rocks was done as follows:

- A $12 \mathrm{~mm}$ double-sided carbon tape was used to cover a $40.0 \mathrm{~mm}$ by $20.4 \mathrm{~mm}$ aluminium stub.

- The carbon tape was then attached to a transparent paper that was cut into $12 \mathrm{~mm}$ by $3 \mathrm{~mm}$ pieces.

- The pieces were then dipped into the finely powdered sample to attach the sample particles.

- The samples were then scanned with a beam of incident electrons operated at -20 $\mathrm{kV}$ to form SEM images on the detector (Kliewer 2009). 
The upgrade level was compared with other cheap and readily available materials like commercial desulphurizer, maize cobs, won out tyres and steel wire. The upgrade materials were reduced in size by cutting into small pieces and packing in the cartridge containers. An inlet and outlet terminals were made on both ends of the containers.
Biogas composition was measured before and after upgrading using a portable biogas analyzer GP180 with a dual wavelength infrared cell with reference channel and an accuracy level of $\pm 0.5 \%$ vol from Henan Ltd, China shown in Figure 3.

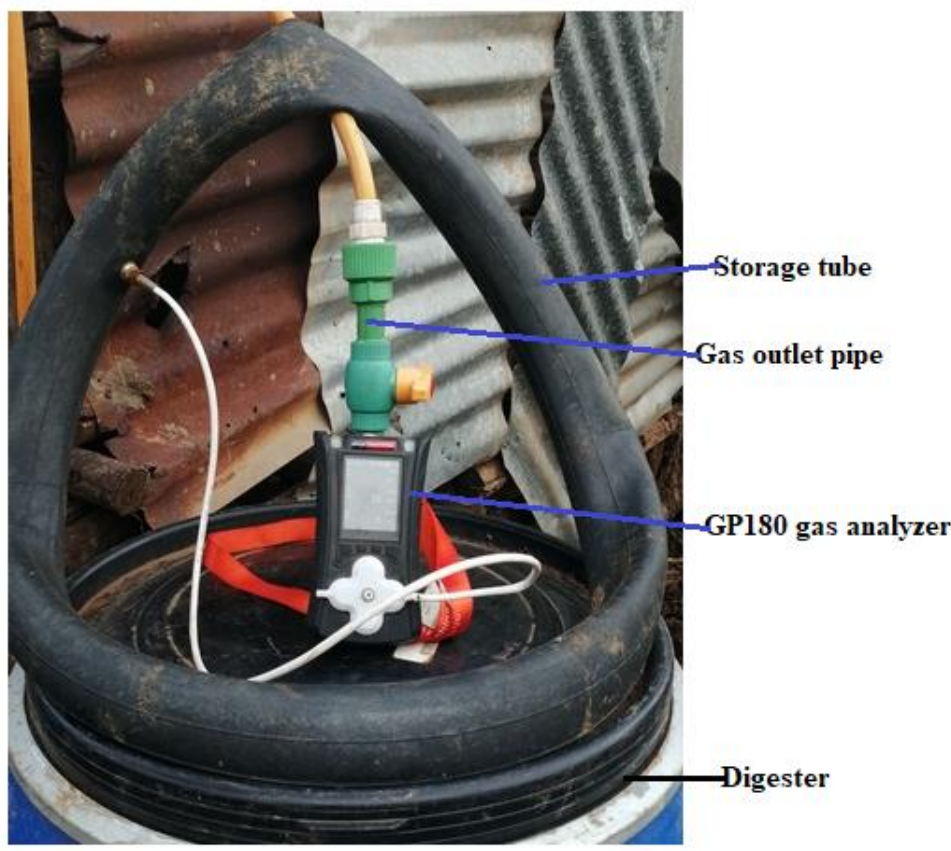

Figure 3: Biogas composition measurements using GP180 in urine bag in tube.

The raw biogas flow rate was done at $0.5-1$ $1 /$ min as efficiency was higher at lower flow rates as observed by Lastella et al. (2002). The control was set by passing the biogas through empty cartridges.

\section{Results and Discussions}

The natural zeolitic rock sample showed that the particles were unevenly sized (Figure 4). The crystals were dense aggregates of irregular shapes, with not well-developed structures on the surface converged particles (Van Donk et al. 2003). Their nonporous nature makes them adaptable for $\mathrm{H}_{2} \mathrm{~S}$ removal from biogas (Simons and Simon 2012). 


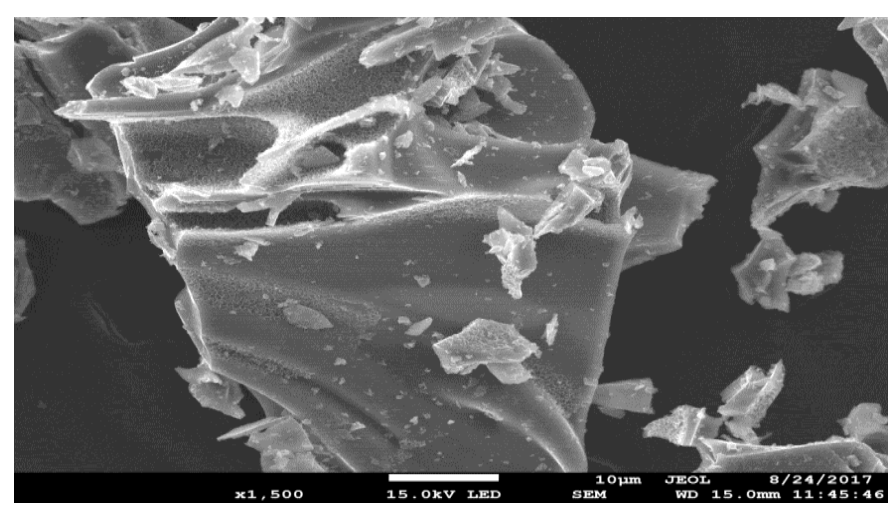

Figure 4: The SEM images of zeolite rock.

The general analysis done on the natural zeolitic rock samples before calcination gave the information recorded in Table 2. The main structural elements of the most natural aluminosilicates are tetrahedra of $\mathrm{SiO}_{4}(\mathrm{~T})$ and/or octahedra of $\mathrm{AlO}_{6}(\mathrm{O})$ joint by the vertices and forming the planar sheets, i.e., tetrahedral and octahedral sheets, respectively (Novikova and Belchinskaya 2016). The natural zeolite-type material from volcanic ash is characterized by the presence of gismondine, hydrated calcium aluminosilicate, litosite, clinoplitolite-Na, and phillipsite-K. The composition depends on the volcanic location, for instance, natural zeolite from Germany have gonnardite $\quad\left(\left(\mathrm{Na}_{5.84} \mathrm{Ca}_{1.6}\right)\right.$ $\left.\left(\mathrm{Al}_{9} \mathrm{Si}_{11} \mathrm{O}_{40}\right) \quad\left(\mathrm{H}_{2} \mathrm{O}\right)_{9.87}\right)$ and mesolite $\left(\left(\left(\mathrm{Na}_{4.96} \mathrm{Ca}_{4.96}\right)\left(\mathrm{Al}_{16} \mathrm{Si}_{24} \mathrm{O}_{80}\right)\left(\mathrm{H}_{2} \mathrm{O}\right)_{23.36}\right)\right.$ zeolite types (Calderón and Quiroz 2020).

Table 2: Composition properties of zeolite rocks

\begin{tabular}{llll}
\hline Property & Properties & Property & Properties \\
\hline Rocks pH & $8.38 \pm 0.52$ & Magnesium $(\mathrm{me} \%)$ & $0.59 \pm 0.07$ \\
Total nitrogen $(\%)$ & $0.10 \pm 0.02$ & Manganese $(\mathrm{me} \%)$ & $0.20 \pm 0.01$ \\
Total carbon $(\%)$ & $0.94 \pm 0.04$ & Copper $(\mathrm{ppm})$ & $1.36 \pm 0.05$ \\
Phosphorus $(\mathrm{ppm})$ & $3.40 \pm 0.12$ & Iron $(\mathrm{ppm})$ & $13.34 \pm 1.29$ \\
Potassium (me\%) & $0.62 \pm 0.04$ & Zinc $(\mathrm{ppm})$ & $10.22 \pm 1.88$ \\
Aluminium oxide $(\%)$ & $18.76 \pm 0.14$ & Silicate oxide $(\%)$ & $37.41 \pm 1.09$ \\
Calcium $(\mathrm{me} \%)$ & $4.70 \pm 0.11$ & Sodium (me\%) & $0.84 \pm 0.03$ \\
Elect. Cond. mS/cm & $0.23 \pm 0.01$ & Me-milli equivalent & \\
\hline
\end{tabular}

The rock samples were moderately alkaline, with minimum organic content. Beside silicon and aluminium which form the main components of zeolites, these samples also had other mineral elements like iron, zinc and calcium as indicated in the Table 2 . The composition of aluminium oxide (\%) and silicon oxide(\%) were $18.76 \pm 0.14$ and $37.41 \pm$ $1.09 \%$, respectively.

The initial biogas composition levels were $>20.00 \pm 2.69 \%, 56.04 \pm 7.56 \%$ and 0.022696 $\pm 6.87 \%$ for $\mathrm{CO}_{2}, \mathrm{CH}_{4}$ and $\mathrm{H}_{2} \mathrm{~S}$, respectively. The $\mathrm{H}_{2} \mathrm{~S}$ levels compared well with those observed by Tira et al. (2015) at $0.024535 \%$. From the control experiments, no upgrade was observed when raw biogas was passed through the empty cartridges. The surface plots obtained for various upgrading materials shown in Figures 5. 
Mbugua et al. - Upgrading biogas using eburru zeolitic rocks and other adsorbent materials ...

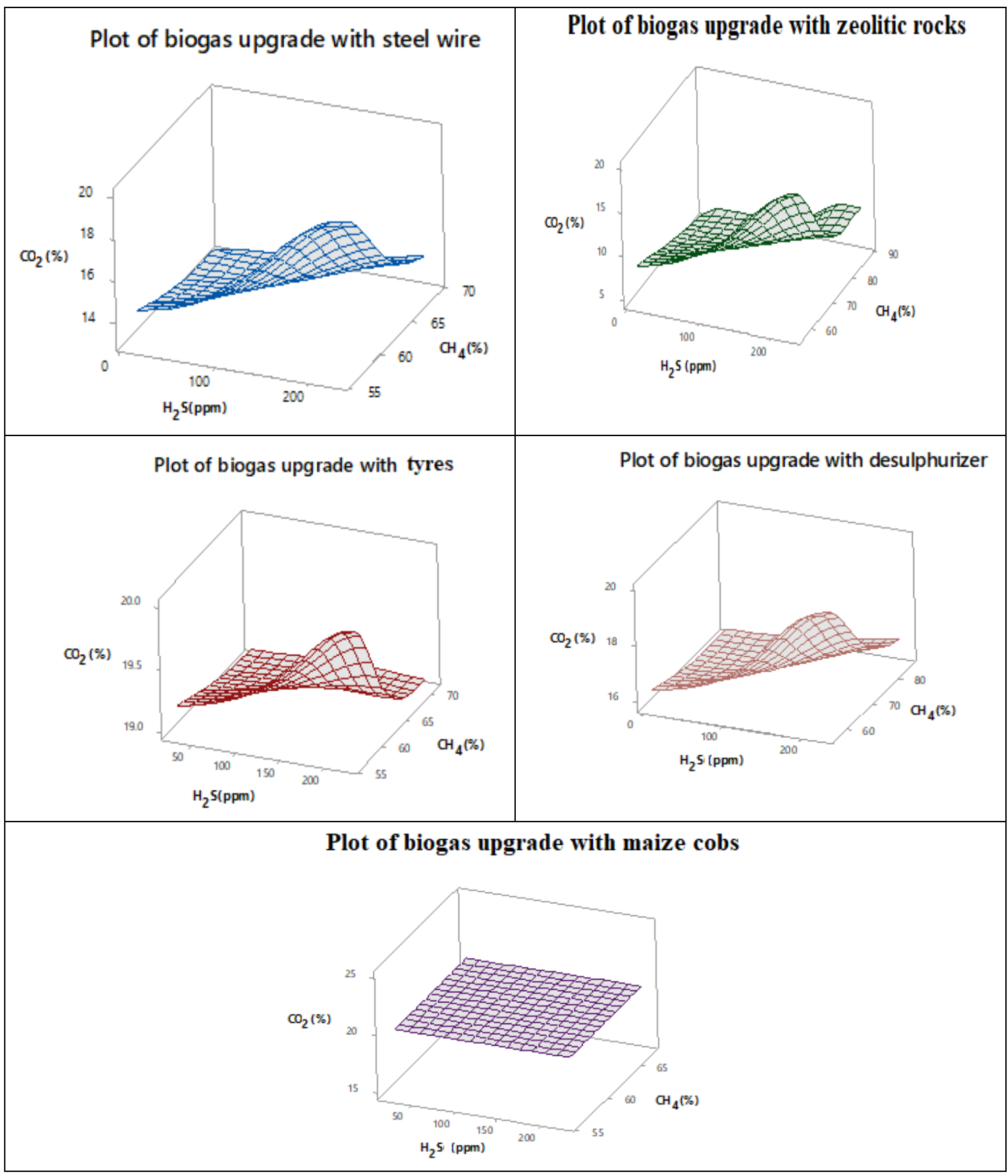

Figures 5: The surface plots of biogas upgrade using different material

The $\mathrm{CO}_{2}$ adsorption onto the zeolite to other upgrading materials at $75 \%$. The high surfaces was observed to be higher compared efficiency of zeolite results from its larger 
porous size translating to deeper penetration (Tira et al. 2018). Previous studies by Tira et al. (2018) reported that increasing corn cobs activated carbon resulted in higher $\mathrm{CO}_{2}$ removal rates.
In Figures 6, comparison of individual biogas composition removal per upgrade material is shown.
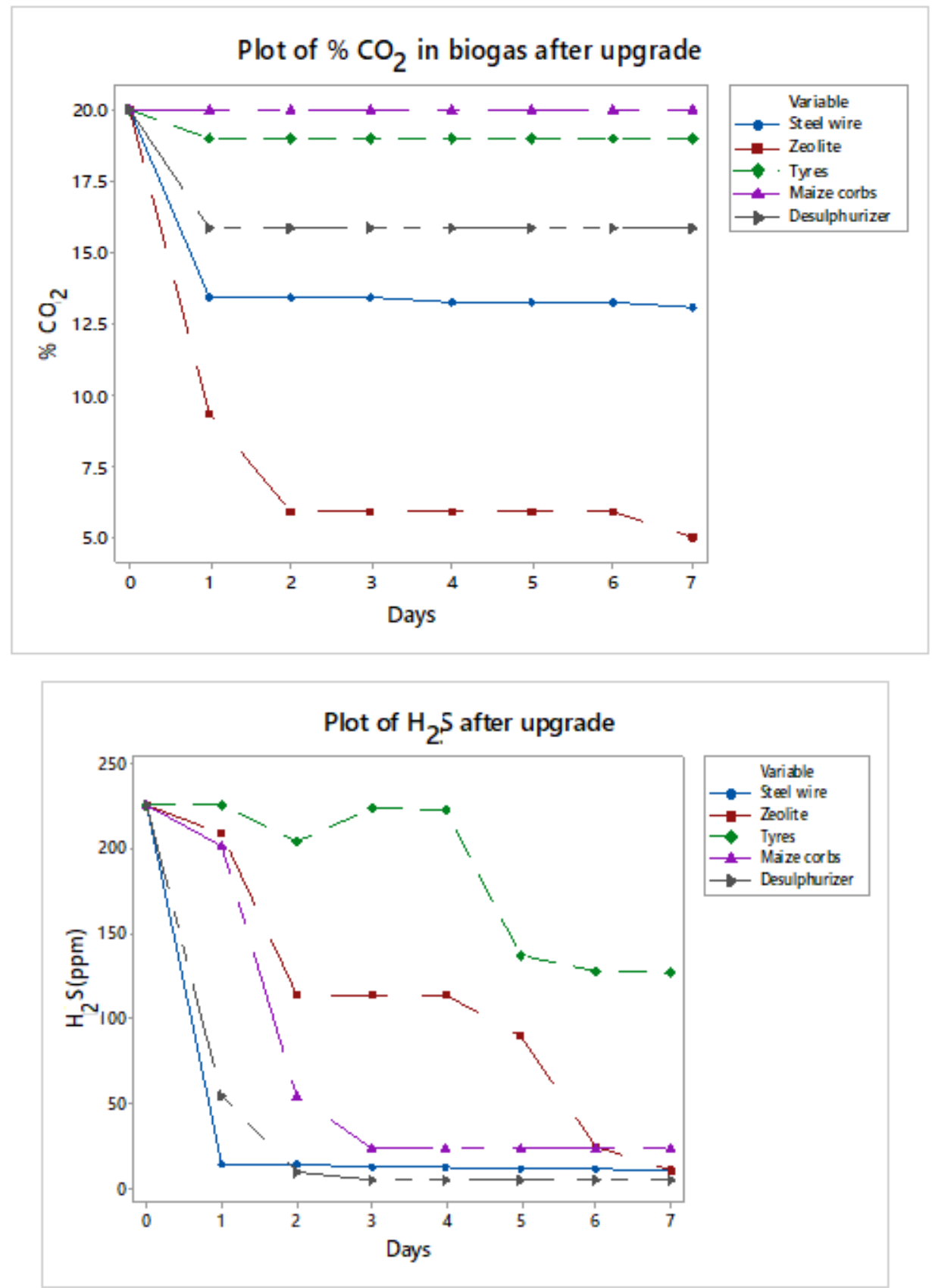


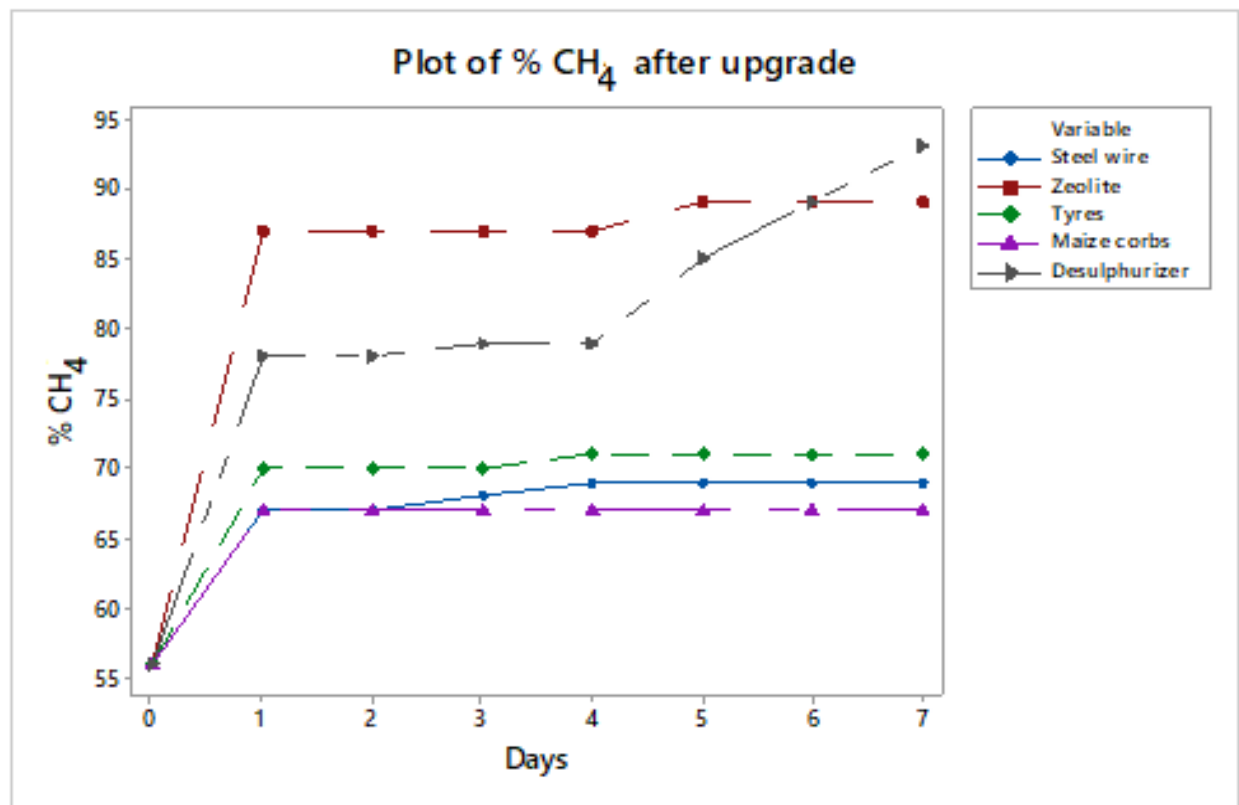

Figures 6: Plots of upgrade levels for each composition.

The adsorption of $\mathrm{CO}_{2}$ predominantly occurred via van Der Waals force. The attractive forces between $\mathrm{CO}_{2}, \mathrm{H}_{2} \mathrm{~S}$ molecules and adsorbent were higher compared to that of $\mathrm{CH}_{4}$ and adsorbent. This resulted in more impurity gases like $\mathrm{CO}_{2}$ being tightly bound in the adsorbent while $\mathrm{CH}_{4}$ molecules tend to pass through the adsorbent (Papagiannakis and Hountalas 2004).
The upgrade levels observed in the pilot scale experiments is shown in Figure 7. The initial level of hydrogen sulphide was $162 \pm$ $15.36 \mathrm{ppm}$ with reduction of up to $2.00 \pm 0.73$ ppm, $6.66 \pm 0.51 \mathrm{ppm}, 3.67 \pm 1.53 \mathrm{ppm}$ being observed in desulphurizer, combined materials and zeolite rocks, respectively.

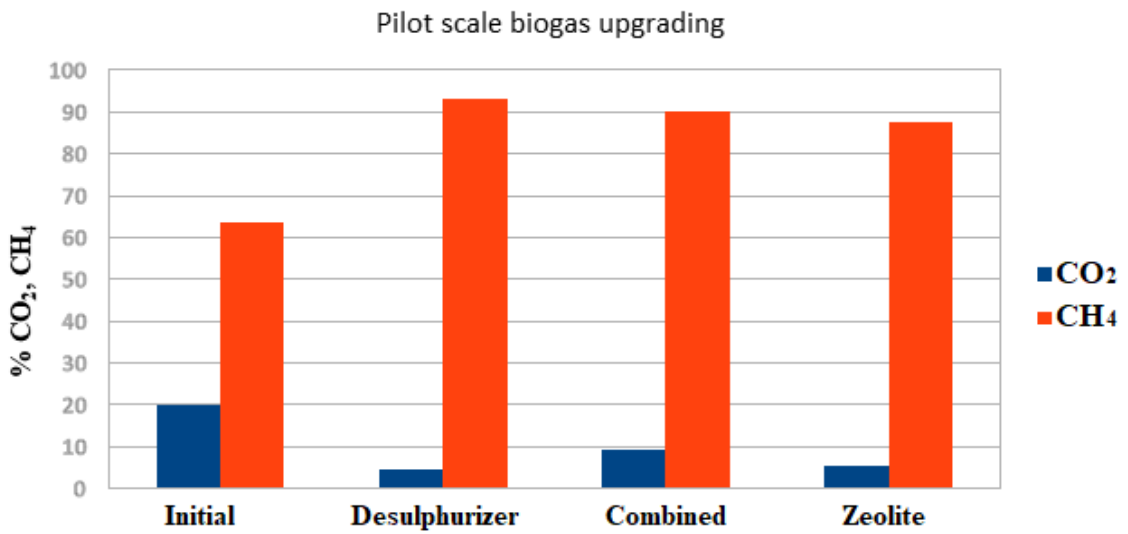

Figure 7: The $\% \mathrm{CO}_{2}$ and $\mathrm{CH}_{4}$ after upgrade of raw biogas. 


\section{Discussions}

The $\mathrm{CO}_{2}$ in biogas reduces its calorific value and lowers the methane levels. This circumstance leads to poor utilization of biogas for electricity generation, transportation or domestic cooking. For these purposes, biogas must have methane levels up to $94 \pm 1.00 \%$ and is termed $\mathrm{CH}_{4}$-enriched biogas (Power and Murphy 2009).

The $\mathrm{H}_{2} \mathrm{~S}$ generated from the digester is in the range of $114.45-263.20 \pm 5.98 \mathrm{ppm}$. The maximum $\mathrm{H}_{2} \mathrm{~S}$ in atmosphere should be lower than $10 \mathrm{ppm}$ as reported by Cosoli et al. (2008). This gas with a rotten egg smell is an extremely hazardous gas, very poisonous and very corrosive. Exposure to very high $\mathrm{H}_{2} \mathrm{~S}$ concentration can result to death (Cruz et al. 2005, Cosoli et al. 2008).

The capacity of $\mathrm{CO}_{2}$ adsorption onto the zeolite micropores was supported due to the propensity of $\mathrm{CH}_{4}$ to get away from the framework resulting in lower molecular transport in the zeolite crystal. This is due to the polar traits of $\mathrm{CH}_{4}$ (Cosoli et al. 2008). This phenomenon offers evidence that hydrophilic zeolite, such as herbal zeolite, has greater affinity for polar molecules like $\mathrm{CO}_{2}$. The presence of $\mathrm{CO}_{2}$ in zeolite micropores tends to force $\mathrm{CH}_{4}$ molecules out from the framework. The planar form molecular shape of $\mathrm{CO}_{2}$ favours the molecules to fit well in the zeolite pores. However, after most zeolite pores have been filled up by $\mathrm{CO}_{2}$ molecules, the adsorption ability declines significantly (Leyssale et al. 2006). It is testifying that adsorption process has a time limit. Duan et al (2007) reported that $\mathrm{H}_{2} \mathrm{~S}$ can be reduced to $0-1 \mathrm{ppm}$ using zeolite material which cannot be achieved by the water scrubbing method (Zhu et al. 2013).

Further, iron oxide reacts with hydrogen sulphide thereby removing $\mathrm{H}_{2} \mathrm{~S}$ from the reactor. Raw biogas is pumped through steel wool, and therefore, iron oxide is converted into elemental sulphur (Katare and Rahi 2016) as shown in Equations 1 and 2.

$$
\begin{aligned}
& 2 \mathrm{Fe}_{2} \mathrm{O}_{3}+6 \mathrm{H}_{2} \mathrm{~S} \rightarrow 2 \mathrm{Fe}_{2} \mathrm{~S}_{3}+6 \mathrm{H}_{2} \mathrm{O} \\
& 2 \mathrm{Fe}_{2} \mathrm{~S}_{3}+3 \mathrm{O}_{2} \rightarrow 2 \mathrm{Fe}_{2} \mathrm{O}_{3}+6 \mathrm{~S}
\end{aligned}
$$

hydrogen sulphide $<1.5 \mathrm{mg} \mathrm{m}^{-3}$ ) was obtained in a study by Paolini et al. (2016), while cleansing biogas from agrozo-technical biomass using natural zeolites. This compares well with the results obtained in this study of $1.05 \mathrm{ppm}_{2} \mathrm{~S}$ and $<2.35 \% \mathrm{CO}_{2}$.

\section{Conclusion}

The work was carried out to find out the potential of various materials in upgrading raw biogas. On average, the methane levels in raw and upgraded biogas was $68 \pm 2.52 \%$ and $90 \pm$ 1.53 , respectively. The results confirm that the zeolitic rocks are superior to tyres, maize cobs, steel wire and desulphurizer in improving biogas quality in removal of $\mathrm{CO}_{2}$. The desulphurizer material suited best in removal of hydrogen sulphide with up to $97.78 \%$ removal rate. The upgrading efficiency of desulphurizer, combined and zeolite material in pilot scale was in the range of 87.67-93.93\% methane and $\mathrm{CO}_{2}$ removal rate of $53.20-77.76 \%$. Therefore, this study recommends a combined adsorbents cartridge to achieve better upgrade levels.

\section{Acknowledgement}

The authors wish to express their sincere gratitude to the National Research Fund (NRF), grants no. 501-000-053 for funding this research work.

\section{References}

Al Mamun MR and Torii S 2015 Removal of hydrogen sulfide (H2S) from biogas using zero-valent iron. J. Clean Energy Technol. 3(6): 428-432.

Amirfakhri J, Vossoughi $\mathrm{M}$ and Soltanieh M 2006 Assessment of desulfurization of natural gas by chemoautotrophic bacteria in an anaerobic baffled reactor (ABR). Chem. Eng. Process. 45: 232-237.

Calderón A and Quiroz HP 2020 Zeolites derived from natural minerals: Solid rock and volcanic ash. Materials Today 34: 148149.

Chambers AK and Potter I 2002 Gas utilization from sewage waste, carbon and energy

Pure bio-methane (carbon dioxide $<0.1 \%$, 
Mbugua et al. - Upgrading biogas using eburru zeolitic rocks and other adsorbent materials ...

management," Alberta Research Council, Canada, pp.1-13.

Cosoli P, Ferrone M, Pricl S and Fermeglia M 2008 Hydrogen sulfide removal from biogas by zeolite adsorption. Part II. MD simulations. Chem. Eng. J. 145: 93-99.

Cozmuta LM, Cozmuta AM, Peter, ANC, Nsimba EB and Tutu H 2012 The influence of $\mathrm{pH}$ on the adsorption of lead by $\mathrm{Na}$ clinoptilolite: Kinetic and equilibrium studies. Water SA 38(2): 269-278.

Cruz AJ, Pires J, Carvalho AP and de Carvalho MB 2005 Physical Adsorption of $\mathrm{H}_{2} \mathrm{~S}$ related to the conservation of works of art: The role of the pore structure at low telative pressure. Adsorption 11: 569-576.

Cu TTT, Nguyen TX, Triolo JM, Pedersen L, Le VD, Le PD and Sommer SG 2015 Biogas production from Vietnamese animal manure, plant residues and organic waste: Influence of biomass composition on methane yield. Asian-Australas. J. Anim. Sci. 28(2): 280-289.

Duan Z, Sun R, Liu R and Zhu C 2007 Accurate thermodynamic model for the calculation of $\mathrm{H}_{2} \mathrm{~S}$ solubility in pure water and brines. Energy and Fuels 21: 20562065.

Kamau JM, Mbui DN, Mwaniki JM and Mwaura FB 2020 Lab scale biogas production from market wastes and Dagoretti slaughterhouse waste in Kenya. Int. J. Energy Environ. Res. 8(1): 12-21.

Katare S and Rahi DC 2016 Biogas purification \& enrichment through stepped scrubbing; Int. J. Eng. Sci. Res. Technol. 5(7): 795-799.

Kliewer CE 2009 Electron microscopy and imaging. In Zeolite Characterization and Catalysis, Springer Science Business Media, 169-196.

Lastella G, Testa C, Cornacchia G, Notornicola M, Voltasio F and Sharma VK 2002 Anaerobic digestion of semi-solid organic waste: Biogas production and its purification. Energy Convers. Manage. 43: 63-75.

Leyssale JM, Papadopoulos GK and
Theodorou DN 2006 Sorption thermodynamics of $\mathrm{CO}_{2}, \mathrm{CH}_{4}$, and their mixtures in the ITQ-1 zeolite as revealed by molecular simulations, J. Phys. Chem. 110: 22742-22753.

Li XQ, Brown DG, and Zhang WX 2007 Stabilization of biosolids with nanoscale zero-valent iron (nZVI). J. Nanoparticle Res. 9 (2): 233-243.

Limmeechokchai B and Chawan S 2007 Sustainable energy development strategies in the rural Thailand: the case of the improved cooking stove and the small biogas digester. Renew. Sust. Energy Rev. 11(5): 818-837.

Mbugua JK, Mbui DN and Kamau GN 2014 Adsorption of dursban (chlorpyrifos) pesticide by loam soil from Limuru, Kenya: Apparent thermodynamic properties. Afr. J. Phys. Sci. 1(1): 1-9.

$\mathrm{Na} \mathrm{K}$ and Somorjai GA 2015 Hierarchically nanoporous zeolites and their heterogeneous catalysis: current status and future perspectives. Catal. Lett. 145(1): 193-123.

Novikova L and Belchinskaya L 2016 Adsorption of industrial pollutants by natural and modified aluminosilicates. In Clays, clay minerals and ceramic materials based on clay minerals. IntechOpen, DOI: 10.5772/61678.

Paolini V, Petracchini F, Guerriero E, Bencini A and Drigo S 2016 Biogas cleaning and upgrading with natural zeolites from tuffs. Environ. Technol. 37(11): 1418-1427.

Papagiannakis RG and Hountalas DT 2004 Combustion and exhaust emissions characteristics of a dual fuel compression ignition engine operated with pilot diesel fuel and natural gas. Energ. Convers. Manage. 45: 2971-2987.

Persson M, Jonsson O and Wellinger A 2006 Biogas Upgrading to Vehicle Fuel Standards and Grid Injection. Report SCG 142, IEA Bioenergy, Task 37-Energy from Biogas and Landfill Gas.

Peterson A 2009 Biogas upgrading and Biomethane Utilization in Sweden. 
Proceedings of the International Conference on Biogas Upgrading, Hanau, 6-8 June, pp. 50-53

Pike Research 2012 Worldwide Power Generation Capacity from Biogas Will Double by 2022. Boulder, USA: Research P 2012, from http://www.businesswire.com/news/home/2 0121107005284/en/Worldwide-PowerGeneration-Capacity-Biogas-Double2022\%20-.U3NpFViSwwk on December 2020.

Power NM and Murphy JD 2009 Which is the preferable transport fuel on a greenhouse gas basis; biomethane or ethanol? Biomass Bioenergy 33(10): 1403-1412.

Ryckebosch E, Drouillon $\mathrm{M}$ and Vervaeren $\mathrm{H}$ 2011 Techniques for transformation of biogasto biomethane. Biomass Bioenergy 35(5): 1633-1645.

Shah DR, Nagarsheth HJ and Acharya P 2016 Purification of biogas using chemical scrubbing and application of purified biogas as fuel for automotive engines. Res. J. Recent Sci. 5:1-7.

Simons T and Simon U 2012 Zeolites as nanoporous, gas-sensitive materials for in situ monitoring of DeNOX-SCR. Beilstein J. Nanotechnol. 3: 667-673.

Tira HS, Padang YA, Salman MW, Wijana M and Anggara RD 2018 The Utilization of corn cob and zeolite as adsorbents for hydrogen sulfide and carbon dioxide removal from biogas. Int. J. Mech. Eng. Technol. 9(9): 545-551.

Tira HS, Padang YA, Mirmanto $M$ and Hendriono H 2015 Improving biogas quality through circulated water scrubbing method. Appl. Mech. Mater. 776: 443-448.

Van Donk S, Janssen AH, Bitter JH and de Jong KP 2003 Generation, characterization, and impact of mesopores in zeolite catalysts. Catalysis Reviews 45(2): 297319.

Waswa GA, Michira IN, Abong'o DA, Andala D and Aluoch AO 2020 Characterization; formulation and application of natural nano zeolitic materials from Kenya as smart delivery systems for fertilizers and pesticides. Int. J. Sci. Res. Sci. Eng. Technol. 7(3): 38-349.

Wellinger A and Linberg A 2000 Biogas upgrading and utilization, IEA Bioenergy Task 24, Paris, France: International Energy Association.

Yan WL, Herzing AA, Kiely CJ and Zhang W 2010 Nanoscale zero-valent iron (nZVI): aspects of the core-shell structure and reactions with inorganic species in water. $J$. Contam. Hydrol. 118(34): 96-104.

Zhu B, Kim JH, Na YH, Moon IS, Connor G, Maeda S, Morris G, Gray S and Duke M 2013 Temperature and pressure effects of desalination using a MFI-type zeolite membrane. Membranes 3: 155-168. 